\title{
FAITH, PURPOSE IN LIFE AND PLACE IN LIFE: A COMPARATIVE STUDY OF HUNGARIAN BREAST CANCER PATIENTS AND HEALTHY WOMEN
}

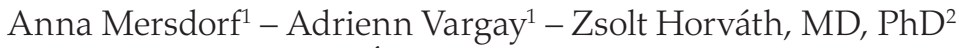 \\ - Éva Bányai, PhD ${ }^{1}$ \\ ${ }^{1}$ University of Eötvös Loránd, \\ ${ }^{2}$ Medical and Health Science Centre Debrecen \\ Corresponding author: Anna Mersdorf E-mail: ansikia@gmail.com
}

\begin{abstract}
In this study the spiritual attitudes (faith, purpose in life and place in life) of 28 Hungarian breast cancer patients and 28 healthy women were compared. The qualitative analysis of the structured interviews indicates that while healthy women have a general framework of belief, not playing an important role in everyday life, breast cancer patients perceive religion as an active aid affecting everyday life. No significant differences were found between the groups concerning purpose in life, place in life, perceived control and sharing thoughts about spirituality with others. The findings of this study contribute to a better understanding of breast cancer patients' psycho-social needs.
\end{abstract}

Keywords: spirituality - faith - purpose in life - meaning of life - breast cancer, structured interview

\section{INTRODUCTION}

Hungary is leading the incidence and mortality rates of all cancer statistics both among women and men. The incidence rate for men in Hungary was 362.4out of 100.000 compared to the European average of 280, while the same data for women was 343.9 and 240 , respectively. The mortality rates had the same tendency: for men/women 183.1/150.1 (Hungarian) compared to 140.1/85.3 (EU average) (Malvezzi et al., 2013; Ferlay et al., 2013; Hungarian Central Statistical Office, 2013).

Perhaps the most devastating trend is that while in the European Union the mortality rates are decreasing year by year, in Hungary, these rates are increasing (Susánszky \& Riskó, 2006). 
This phenomenon has an unquestionably complex bio-psycho-social background worth to be examined holistically.

\section{SPIRITUALITY, FAITH AND RELIGIOSITY}

Spirituality, faith, religiosity, meaning in life and purpose in life are concepts often used as synonyms. Although there are common areas in spirituality (including meaning in life and purpose in life) and religiosity (Horváth-Szabó et al., 2009) in psychology religion and spirituality are clearly different processes, both consisting of complex, interpersonal, behavioral, cognitive, emotional, and physiological elements (Hill \& Pargament, 2008). Multidimensional statistical analysis also confirms that spirituality is a distinct domain of human experience (Tomcsányi et al., 2011).

Muldoon \& King (1995) defined spirituality as "the way in which people understand and live their lives in view of their ultimate meaning and value" (p. 336). Spirituality is often perceived as a universal connection to the transcendent and as a search for meaning in life that may or may not be linked to a divine figure (Muldoon \& King, 1995). According to Emblem (1992), religiosity, in psychological research, is conceptualized as an organized set of beliefs, rituals, and practices engaged in with the goal of connecting to a higher power such as God (cited by McClain-Jacobson et al., 2004). Based on Gordon Allport's theoretical distinction (Allport \& Ross, 1967 cited by Herek, 1987) religiosity can be divided into two religious orientations: an intrinsic religiosity signifying a meaning-endowing framework which integrates life events, and an extrinsic orientation that can be described as self-serving, instrumental approach conforming to social conventions.

In the past few years, much attention has been given to the multidimensional measurement of religiosity (Dormán et al., 2012; Farkas \& Gerevich., 2005; Martos et al., 2009; Miller, W. R., \& Thoresen, C. E. 2003) that is examined as a complex phenomenon with many correlates. This approach also means that the research methodology of this topic has also to be complex, and that the interpretation of results can be quite (Bergin, 1983).

\section{PURPOSE IN LIFE AND MEANING OF LIFE}

The concept of meaning of life can be connected to Viktor Frankl. As Konkoly and Martos et al. (2006) and Konkoly, Martos, Skrabski \& Kopp(2008) emphasize that, in Frankl's opinion (1959; Frankl, 2006), to have meaning in one's life plays an important role in mental health. It is very important for a person to have meaningful strivings, and to reach these aims. It is also 
significant what the individual's attitude towards unchangeable and bad situations is.

When talking about purpose in life, long-term aspirations are positively correlated with health according to Kasser and Ryan (1996). They developed the Aspiration Index questionnaire on the basis of Deci and Ryan's $(1987,2002)$ Self Determination Theory that emphasizes the importance of the distribution of extrinsic and intrinsic goals inside the personality. As Martos et al. (2006) also mentions, for a healthy personality, having intrinsic goals is a necessity.

Connection was found between intrinsic aspirations and greater mental and physical well-being, and extrinsic aspirations and worse mental and physical well-being (V. Komlósi et al., 2006). Extrinsic motivation (seeking extrinsic rewards and coming up to extrinsic expectations)correlates with worse health outcomes both on short- and long term (Martos et al., 2006).

\section{BIO-PSYCHO-SOCIAL CORRELATES OF RELIGIOSITY AND SPIRITUALITY}

As mentioned above, purpose in life and meaning of life seem to have an effect on mental and physical health. Many further findings suggest that there are complex associations between spirituality, religiosity and physical, emotional and social functioning.

For example, there are links discovered between certain religious practices (e.g. prayer and confession) and reduced occurrence of mental and physical illnesses, reduced mortality and adjustment to and recovery from mental or physical illness (George, et al., 2000).

Intrinsic religiosity also seems to have certain health benefits. When exposed to laboratory stressors, including interpersonal confrontation, older extrinsically religious individuals showed exaggerated cardiovascular reactivity compared to older intrinsically religious individuals and younger participants (Masters et al., 2004).

Intrinsic religiosity seems to have positive psychological correlates too, such as better mental health (self-esteem, meaning in life, family relations, a sense of well-being), but not enough evidence was found supporting that religiousness plays a role in the prevention of serious clinical diagnoses such as panic disorders, schizophrenia or bipolar disorders, according to Payne et al. (1991).

In the review article of McCullough and Larson (1999), the connection of depression and religious involvement was examined. Although there were some tendencies explored between the two topics (intrinsic religiosity is connected to a reduced risk of depressive symptoms), more investigation is needed for significant results.

Religiousness and religious support include social support as well that provides both instrumental and psychological advantages and is associated with 
lower levels of depression, and positive affect on life satisfaction. This support can be especially useful when dealing with stressful situations (Fiala et al., 2002).

\section{THE POSSIBLE UNDERLYING PROCESSES EXPLAINING THE EFFECTS OF RELIGION AND SPIRITUALITY}

There are many complex underlying processes that can contribute to the healthprotecting effects of religiosity. Mediating factors connected to religion and spirituality like social support, a framework for life and existence, meaningful set of aspirations, specific emotion regulation and coping mechanisms, posttraumatic growth, and finding meaning for traumatic situations all play an important role in positive health outcomes.

As seen above, social support can be a mediating factor between spirituality and health, and religiosity seems to develop health protecting behavior and a sense of coherence as well (George et al., 2000).

Psychologists hold the idea that for some people religion and spirituality are special frameworks that provide orientation and motivation in their life (Pargament, 2001). This framework for example can give sense to one's existence and can give strength for reaching spiritual and everyday goals even in critical times (Baumeister, 1991). What is more, spirituality and religion offer a clear way for reaching goals through coping mechanisms such as prayer and meditation. Religion is therefore an important contributor in the set of personal goals (Kézdy \& Martos, 2007; Martos \& Kézdy, 2007; Martos et al., 2011).

There are many positive emotions connected to religiosity such as thanksgiving, joy, and sharing these feelings with other companions. Religion also offers specific ways to regulate negative emotions including forgiveness, mindfulness, rituals, emotional and cognitive coping mechanisms (HorváthSzabó et al., 2009).

Connection was found between religiosity and mental health with the mediating factor of problem-focused and adaptive emotion-focused coping mechanisms within two age groups. While in the case of high-school students, the frequency of church attendance and transcendent involvement proved to be contributing to better mental health, in the case of university students, symbolic representation was observed as the corresponding adaptive coping mechanism. These results could perhaps indicate that church attendance does not correlate with better health per se, but that the use of religion-specific coping mechanisms such as helping others, expression of emotions in an adaptive way, and a meaningful framework for life (Kézdy, 2010; Kézdy et al., 2010).

To understand these mechanisms, it is to be noted that religion and spirituality are not only a set of practices and beliefs separated from everyday 
life and used at certain occasions, but are ways of life affecting many dimensions of human existence and social activity (Hill \& Pargament, 2008).

\section{SPIRITUALITY AND RELIGIOSITY AS A COPING MECHANISM FOR CANCER PATIENTS}

As discussed above, the effect of religion, faith, and spirituality on physiological and psychological health was examined by many studies. As cancer is a disease gaining more and more attention, it is also relevant to explore how religion and spirituality might help in coping with cancer.

The role of religiosity as a protective factor against cancer mortality and as a factor slowing the progression of cancer was thoroughly examined by Powell, Shahabi and Thoresen (2003). The results of their review clearly show that religious attendance is not an independent protective factor against cancer mortality and progression.

However, a considerable amount of studies examined and found a connection between faith, spirituality and religiosity on one side, and between coping with cancer and adjustment to illness on the other side.

Religion was found to be an extremely important resource for the majority of 103 breast cancer patients examined in the study of Johnson and Spilka (1991), and the intrinsic religious orientation was identified as a useful coping strategy for breast cancer patients. Holland et al. (1999) found significant correlation between the use of active-cognitive coping style and a greater reliance on spiritual and religious beliefs among 17 ambulatory patients coping with malignant melanoma. Their findings suggest that a useful active-cognitive framework is provided by religious beliefs for many individuals facing the existential crisis of a life-threatening illness.

In the longitudinal study of Yates, Chalmer, James, Follansbee and McKegney (1981) conducted with 71 patients with advanced cancer, religious belief also showed a substantial positive correlation with life satisfaction and happiness. It seems that these benefits were due to different religious coping methods: putting trust in God concerning the course of their illness, maintaining belief in the afterlife(and therefore being less afraid of death), finding blessings in their lives, and appraising their cancer experience in a more constructive, religious light.

As a result of a correlational study conducted with 114 adults diagnosed with cancer, a consistent inverse relationship was found between spiritual wellbeing and state and trait anxiety, regardless of gender, age, marital status, diagnosis, group participation, or the time past since acquiring the diagnosis. This supports the theory that people with high levels of spiritual well-being have lower levels of anxiety (Kaczorowski, 1990). 
Fehring, Miller and Shaw's (1997) study presents results showing that intrinsic religiosity and spiritual well-being among elderly people coping with cancer were associated with hope and positive mood states. A consistent positive correlation was found among intrinsic religiosity, spiritual well-being, hope, and other positive mood states. Among intrinsic religiosity, depression, and other negative mood states, a consistent negative correlation was established.

Studies examining spirituality and purpose in life among breast cancer patients and healthy women (using the Purpose in Life Test) did not find significant difference between these two groups (Jonsén et al., 2010; Sarvimaki \& Stenbock-Hult, 2000; Coward, 2003; Lee, 2006; Pinquart, 2009). Therefore breast cancer patients' attitude towards purpose in life does not differ from healthy controls' attitude, although in the case of other diseases, findings show significant differences. One possible explanation for his result could be that breast cancer patients use attributions to purpose in life and meaning of life as a specific coping mechanism (Mersdorf et al. 2013).

The findings above showed that no reliable connection was found between physiological health and spirituality; however, according to many findings, spirituality is an important psychological resource for patients coping with cancer. Religion and spirituality are important resources for patients facing a life threatening, physically and spiritually demanding disease such as cancer (Feher \& Maly, 1999; Jenkins \& Pargament, 1995). As Martos (2007) cites Park (2005), in certain hard situations (diagnosis of cancer, sexual abuse, loss of an important person), religiosity as a positive coping mechanism can also be correlated with posttraumatic growth.

\section{RELIGIOSITY/SPIRITUALITY AMONG THE HUNGARIAN POPULATION}

All the above mentioned studies were conducted in English-speaking populations; however, since the present study was conducted in a Hungarian population, religious characteristics of the Hungarian population should be described.

According to 'Hungarostudy 2002', a representative study of the Hungarian population ( $n=12.600$ ) (Kopp, Székely \& Skrabski, 2006), 25\% of the Hungarian population reported themselves as a non-believer, $18 \%$ as not practicing any religion, $27 \%$ as being a believer in their own way, $17 \%$ as rarely and $13 \%$ as regularly practicing religion. The results of 'Hungarostudy 2002' show that 'religious practice' had positive health effects: less days of illness, better workability, higher scores on the WHO well-being questionnaire, fewer depressive symptoms, less hostility, more cooperation, less emotion-focused coping (e.g. smoking), more problem focused coping, and more perceived social support characterize people with religious practice as compared to people without such 
practices. The 'importance of religion' correlated with less smoking, consumption of less short drinks, higher levels of cooperation, and more adaptive coping strategies. However, the 'importance of religion' likewise correlated with greater depression and decreased work ability. These correlations suggest that religion becomes more important for people living with chronic illness (Kopp, Székely \& Skrabsky, 2006).

\section{Research questions}

Based on the presented literature, in our study, we wanted to search for answers to the following questions:

- Are healthy women and breast cancer patients religious, or do they have a non-religious faith?

- Do they have meaning and purpose and place in life? Do they have a social network, i.e. people with whom they can share these thoughts?

- Do healthy and breast cancer patients have different thoughts about these topics?

- Do healthy and breast cancer patients use spirituality and religion as a coping mechanism, and if yes, in what specific way?

The study

The present study was conducted with the cooperation of the Center for Affective Psychology, Institute of Psychology, Faculty of Education and Psychology, University of Eötvös Loránd, Budapest, Hungary, and the National Institute of Oncology (NIO) (both institutions are located in Budapest, Hungary). The bio-psycho-social research project consisted of two main parts:

1. exploration of the psycho-social attitudes and the characteristics of breast cancer patients (the results of this study are presented below),

2. studying the effects of hypnosis as an adjuvant therapy in the treatment of breast cancer patients (ongoing study).

In this article, we would like to present the results of the explorative study concerning the attitudes and characteristics of the women taking part in the first research project regarding faith, religiosity, purpose in life, and the meaning of life. We would also like to find out if there are any differences between healthy and breast cancer patients in the dimension of spirituality, and to examine whether spirituality and religiosity is used as a coping mechanism facing a life threatening illness like cancer.

\section{METHOD}

Study sample

In our study, breast cancer patients and healthy women were included. In the breast cancer (BC) group 31 breast cancer patients were recruited: 27 patients 
of the NIO and 4 people via the National Association of Cancer Patients: Solstice Service of Nyíregyháza (a city in Eastern Hungary with a population of 116.000). Entrance criteria were the diagnosis of breast cancer, being an ambulatory patient receiving medical treatment, speaking fluent Hungarian, and willing to give a voluntary, written informed consent. At the NIO, patients were personally contacted by members of the research team in the waiting area or chemotherapy treatment room of the hospital, or by their physician. After a short verbal explanation and the distribution of written descriptions of the study, they were invited to participate. In case of the National Association of Cancer Patients: Solstice Service of Nyíregyháza, the local psychologist recruited the patients from among the attendants of the service in the same manner. From the original sample, one person was excluded due to having colorectal cancer, one person used her right to suspend the digital voice recorder that recorded the interview (her interview, therefore, was omitted from further analysis) and in one case, the interview could not be finished due to time limits. In the final sample, 28 women were included. Table 1 shows the pathology of the BC group from the National Institute of Oncology and the National Association of Cancer Patients: Solstice Service of Nyíregyháza.

\begin{tabular}{llc} 
TYPE & STATUS & $\begin{array}{c}\text { NUMBER } \\
\text { OF PATIENTS }\end{array}$ \\
\hline Triple negative & Advanced & 1 \\
\hline Triple negative & Early stage & 1 \\
\hline HR-negative, HER2-negative & Advanced & 2 \\
\hline HR-negative, HER2-positive & Advanced & 1 \\
\hline HR-negative, HER2-positive & Recurrence & 1 \\
\hline HR-negative, HER2-positve & Early stage & 6 \\
\hline HR-positive, HER2-negative & Advanced & 4 \\
\hline HR-positive, HER2-negative & Early stage & 1 \\
\hline HR-positive, HER2-positive & Advanced & 3 \\
\hline HR-positive, HER2-positive & Early stage & 6 \\
\hline Missing data & Advanced & 1 \\
\hline Missing data & Early stage & 1 \\
\hline
\end{tabular}

Table 1 Pathological description of the breast cancer sample group: The table describes the type and status of cancer of $\mathrm{BC}$ women participating in the study. ( $\mathrm{HR}=\mathrm{Hormone}$ Receptor)

In the BC group, out of 28 patients, 15 had early stage breast cancer, 12 had advanced stage breast cancer, and 1 had recurrence.

The healthy control (HC) group was recruited through newspaper advertisement and social network websites. In order to represent the diversity of residence of the $\mathrm{BC}$ group, a local psychologist and a teacher from the Eastern and Western part of the country (cities of Nyíregyháza and Szombathely) were asked to recruit healthy women to match the sample group. Inclusion criteria were being healthy, lack of any chronic physical or mental illness, speaking fluent Hungarian, and being willing to give a voluntary written informed 
consent. Altogether 35 healthy women were interviewed, out of which 4 were excluded for medical reasons, and 1 because of psychiatric disorder. Out of the remaining 30 women, those 28 were picked who best matched the sample group in terms of socioeconomic status.

Table 2 shows the characteristics of the final sample of our study.

\begin{tabular}{lll} 
& BREAST CANCER GROUP & HEALTHY CONTROL GROUP \\
\hline Sample size $(\mathrm{n})$ & 28 & 28 \\
\hline Health status & Breast cancer & Healthy \\
\hline Gender & Female & Female \\
\hline Average age (year) & 53.4 & 49.8 \\
& (Sx=9.8 year) & (Sx=8.6 year) \\
\hline Average income & $87.500 \mathrm{HUF}$ & $103.800 \mathrm{HUF}$ \\
(1 person in the family/ & (Sx=29.500 HUF) & (Sx=52.500 HUF) \\
1month in HUF and & $314.74 \mathrm{EUR}$ & $370.5 \mathrm{EUR}$ \\
approximated value in EUR) & (Sx=106.1 EUR) & (Sx=188.8 EUR) \\
\hline
\end{tabular}

Table 2 Health related, gender, age and socio-demographic characteristics of the study sample.

As shown in Table 2, only females participated in both groups, the average age of the BC group was 53.4 years (SD 9.8), while the average age of the HC group was 49.8 years (SD 8.6). The distribution of age categories in the BC group was the following:: 1 person aged 30 to 39 years, 4 persons aged 40 to 49 years, 17 persons aged 50 to 59 years, 3 persons aged 60 to 69 years, and 3 persons over 70 years. The average income per month in the family, converted from HUF, was about 314.74 EUR (SD 106.1) in the BC group, and 370.5 EUR (SD 188.8) in the HC group (1 EUR equals to $278 \mathrm{HUF}$ at the time of the writing of this article). According to the independent sample t-test, the two groups do not differ significantly in terms of age or income.

\section{Procedure and ethics}

After receiving a short verbal explanation and the written description of the study, a separate date was set for the interview when the written informed consents were signed by the participants. In the case of the BC group, the date of the interview always concurred with the date of a treatment or a laboratory examination in order to avoid extra effort on their behalf. All participants gave their consent in writing to the use of a digital voice recorder, with the right of suspending it any time. All participants were informed about their right of being entitled not answering not answering certain questions or finishing the interview at any point.

Two researchers conducted the face-to-face interviews in a calm environment, where it was possible to talk without disturbance. The interviews lasted about 1.5 hours. In the case of the BC group, a medical staff room was granted for the purposes of the research team at the National Institute of Oncology, while 
the National Association of Cancer Patients: Solstice Service of Nyíregyháza provided two rooms for the time of the interviews. The interviews in Budapest, Nyíregyháza and Szombathely were conducted in the rooms of the Institute of Psychology at Eötvös Loránd University, in a private psychological center and in an elementary school, respectively.

Ethical approval for the study was granted by the Ethical Committee of the National Institute of Oncology. Each participant could contact the researchers via e-mail and telephone before and also after the interviews with any sort of questions or request for help. All personal data were handled in accordance with the due ethical requirements. Participation was voluntary. Although the interviews were not meant to provide therapeutic help, in many cases they invoked deep emotions.

In order to grant the psychological well-being of the interviewers, the help of a supervisor was provided by the Institute of Psychology, Eötvös Loránd University.

\section{MEASURING INSTRUMENT}

Development of the Complex Clinical Structured Interview - for Breast Cancer Patients (CCSI-BCP)

It is well established that the psycho-social background of cancerous diseases is most complex, therefore a likewise complex approach is needed to gather information about it. In order to avoid using an impersonal self-report instrument package that in many cases contains unintended implicit negative suggestions that restrict answers, a structured interview was developed (Mersdorf et al., 2013).

Besides gathering unrestricted information without negative suggestions, the aim of the interview method was to create personal contact with patients and to provide a setting where their lives, problems, emotions, and thoughts are received with due attention. According to feedbacks, the interviews not only provided the research team with the necessary information for datacollection, but also BC patients (and healthy women as well) a chance for a deeper understanding of their emotions, relations and life events while facing a life threatening illness.

Although it is an explorative study, standardized questionnaires were taken into account for the development of the questions of the structured interview. The CCSI-BCP was based on the following four standardized self-report instruments:

1. SF-36v2 Health Survey (Version 2.0) - (Ware \& Gandek,1994; Ware, 2002)

2. The Hungarian version(Hammer, 1995) of the Perceived Social Support Questionnaire -(Turner \& Marino, 1994) 
3. The Hungarian version of the Purpose in Life Test - (Crumbaugh \& Maholick, 1964; Crumbaugh, 1968; Konkoly \& Martos, 2006)

4. The Hungarian version of the Kasser and Ryan's (1996) Aspiration Index (Martos, Szabó \& Rózsa, 2006)

The questions of the interview were focused on the following six topics: 1.) physical health (previous 12 months and life-span) 2.) attributions of health and illness 3.) psychological well-being and milestone life events (previous 12 month and life-span) 4.) social structure and important relationships (with an emphasis on physical contact) 5.) control 6.) spirituality.

The sixth topic, spirituality, was set as the focus of our present study, therefore the interviews consisted of the following groups of questions within this topic:

6a) faith, religiosity (Do you believe in God or in a higher power? Do you have some kind of a personal belief system? Do you practice a religion?)

6b) purpose in life (Do you think you have a purpose in your life? If yes, what is this purpose?)

6c) meaning of life (Do you think your life has a meaning? If yes, what is this meaning?)

6d) place in life (Do you feel you have found your place in life?)

6e) sharing thoughts about spirituality with others (Do you have somebody to share your thoughts with about the above topics, or are you, for example, the member of a congregation?)

6f) perceived control concerning these topics (How much control do you think you have in finding your place in the life, finding a purpose or meaning in your life, and having a belief in God or some other belief system? Does it depend on you, on your family traditions, or on some other influences?).

\section{SOME EXAMPLES FOR ANSWERS GIVEN TO THE QUESTION OF FAITH AND RELIGIOSITY}

Below presented are some examples of how cancer patients answered for the QG faith and religiosity (6a).

„....it's a good question. I'm not baptized; my mother comes from a religious family, but she doesn't believe in God. But it's very interesting that when I was a child, I learned how to pray myself, and I say my own prayer almost every evening. And I know that someone cares for me very much, and forms my life in a way that I can be satisfied."

"Yes, I believe in God. It doesn't really matter to me whether it exists or not. I feel his presence, and this is what gives me power many times. I'm living by my personal 
faith, I don't go to church often, but in case I pass by one, I enter and give thanks for the past two decades."

Yes, I think of myself as a believer. The organizing power for everything is love. For me, God is a synonym for love. God gives us love, but he doesn't influence us how we deal with it. This can explain many bad things in the world, wars, for example."

"I don't belong to any religion, but I believe in some power that guides the world, and to make it simple, we can call it God."

"I'm Catholic, I believe in God, and I go to church regularly. Prayer helped me a lot in my opinion. During radiotherapies, I always said an Our Father to myself under the machine, and when I had been finished, the therapy was over too."

"It's a good question, because since I became ill, I have started to believe in many things I didn't before. So now it's different. I go to a congregation regularly, but I also like to be alone and meditate on spiritual matters. The priest and other people belonging to this community are great too, they helped a lot when it became known what had happened to me. ... A lot of positive things happened to me through this illness. Or am I just thinking it now? I don't know whether things went on the same way in the past or not. But now, I think things go better.

"I'm Catholic. And if something bad happens to me, sometimes, I can see the good in it too. Something happens for a reason; it was bad, but at the end, it turned out that, in fact, it was good."

\section{Analytic Methods}

The digitally recorded 1-1.5 hour long interviews were transcribed, and the verbatim transcripts were used for further content analysis.

\section{DATA ANALYSIS}

The development of the category system

The answers of breast cancer patients and healthy women were analyzed by using qualitative content analysis. The category system of the qualitative content analysis was developed based on the method of 'grounded theory' (Glaser \& Strauss, 1967; Strauss, 1987; Charmaz, 2000; Charmaz \& Henwood, 2008).

Using the verbatim transcribed text, answers for the above-mentioned question groups (QGs) were selected and listed. For each question of each QG (e.g. do you think you have a purpose in your life?) the full-length answers (e.g. 'Well, I've never thought about it... but yes, I can tell have a purpose. 
Raising my children, being with my husband, ... and of course my job are also important to me .... I always liked to work as a teacher .... and ... and to do as much as I can for helping people who are in need of something.') were selected and reduced to short answers (children, husband, job, helping others), and these 'shortened' answers were listed below each other. The list was read repeatedly by three members of the research group and analyzed for emerging themes (e.g. children, husband, job, social responsibility, etc.) in order to create a category system.

For the topic spirituality, 3 independent category systems were developed and compared by 3 independent judges. After reaching consensus on slight differences concerning the three independent category systems, 54 categories emerged for question groups from $6 \mathrm{a}$ to $6 \mathrm{f}$. These categories were named and used as code-labels (e.g. children) for the content-analysis (Table 3, $3^{\text {rd }}$ column).

Since participants could not grasp the difference between purpose in life and meaning of life, and therefore, gave exactly the same answers for the two questions, these two were merged together, and in the further analyses, it was treated as one question group: purpose in life (PIL).

\section{Coding of the interviews}

After developing the category system, the Atlas-ti4.1 software (Software for Qualitative Data Analysis) (Muhr, 1997) was used by two independent raters for the content analysis of the transcribed, verbatim material. Independent raters categorized the written texts of the interviews into the 54 categories of the category system.

\section{Analytic Variables}

Using these 54categories, a total of 425 answers were identified in the 56 transcripts. Considering the size of the sample the sample size, the number of categories were too numerous for analysis. For a meaningful statistical analysis, the categories had to be combined into main categories (MCs). The development of the MCs for the question groups Purpose in Life (PIL) and Place in Life (PlaceIL) were partly based on the subscales of the Hungarian version of Kasser and Ryan's Aspiration Index (Martos, Szabó \& Rózsa, 2006). Independently from the Aspiration Index, the same Main Categories emerged from the answers of the study sample regarding this QG (Mersdorf et al., 2013). The English version of the Aspiration Index (Kasser \& Ryan, 1996) contains 7 subscales grouped into an Intrinsic subscale group (Self-Acceptance, Affiliation, Community Feeling, Physical Fitness subscales) and an Extrinsic subscale group (Financial Success, Attractive Appearance, Social Recognition subscales). In the Hungarian version, Physical Health belongs neither to the Intrinsic, nor to the Extrinsic subscale-group. 


\begin{tabular}{|c|c|c|}
\hline $\begin{array}{l}\text { QUESTION } \\
\text { GROUPS }\end{array}$ & $\begin{array}{l}\text { MAIN } \\
\text { CATEGORIES }\end{array}$ & $\begin{array}{l}\text { CONTENT OF MAIN CATEGORIES } \\
\text { EXAMPLES OF CATEGORIES/CODES }\end{array}$ \\
\hline \multirow[t]{3}{*}{ Faith } & $\begin{array}{l}\text { 1. Has some kind of } \\
\text { a belief-system }\end{array}$ & $\begin{array}{l}\text { 1. Has some kind of } \\
\text { a belief-system }\end{array}$ \\
\hline & $\begin{array}{l}\text { 2. Has a belief system that } \\
\text { helps her in everyday life }\end{array}$ & $\begin{array}{l}\text { 2. Has a belief system that } \\
\text { helps her in everyday life }\end{array}$ \\
\hline & 3. Does not believe & $\begin{array}{l}\text { 3. Does not believe in any } \\
\text { belief system/ } \\
\text { She is not sure she believes or not/ } \\
\text { Religion is a formality only, } \\
\text { without real belief/ } \\
\text { Religion is important for social } \\
\text { support only and not for belief. }\end{array}$ \\
\hline \multirow[t]{3}{*}{ Purpose in life } & 1. Personal improvement & $\begin{array}{l}\text { 1. Yes, through ... her goals coming true/ } \\
\text { feeling good, being happy }\end{array}$ \\
\hline & 2. Important social connections & 2. Yes, through her ... family/ children \\
\hline & 3. Social commitment & $\begin{array}{l}\text { 3. Yes, through ... helping others/ } \\
\text { working for the sake of a society/ } \\
\text { Creating something long-lasting }\end{array}$ \\
\hline \multirow[t]{4}{*}{ Place in life } & 1. Personal improvement & $\begin{array}{l}\text { 1. Yes, through her ... goals coming true/ } \\
\text { feeling good, being happy }\end{array}$ \\
\hline & 2. Important social connections & 2. Yes, through her ... family/children, etc... \\
\hline & 3. Social commitment & 3. Yes, through being useful, etc... \\
\hline & 4. Did not find place & $\begin{array}{l}\text { 4. Did not find her place ... in general/ } \\
\text { in marriage or partner relationship/ } \\
\text { in work/financially/etc... }\end{array}$ \\
\hline \multirow[t]{4}{*}{ Sharing with others } & 1. Does not have & $\begin{array}{l}\text { 1. Does not have/ } \\
\text { Does not even demand to have/ } \\
\text { She would demand, but has } \\
\text { no chance to have /etc.. }\end{array}$ \\
\hline & 2. Has, a family member & 2. Has, a family member \\
\hline & 3. Has, wider social structure & $\begin{array}{l}\text { 3. Has, friends (not relatives)/ } \\
\text { Has, a community }\end{array}$ \\
\hline & 4. Not classifiable & $\begin{array}{l}\text { 4. Not a specific person/ } \\
\text { Not classifiable }\end{array}$ \\
\hline \multirow[t]{4}{*}{ Perceived control } & 1. Perceives control & 1. Perceives control \\
\hline & 2. Does not perceive control & 2. Does not perceive control \\
\hline & $\begin{array}{l}\text { 3. Partly perceives } \\
\text { control } 50-50 \%\end{array}$ & $\begin{array}{l}\text { 3. Partly perceives } \\
\text { control } 50-50 \%\end{array}$ \\
\hline & 4. Not classifiable answer & $\begin{array}{l}\text { 4. Not classifiable answer/ } \\
\text { Does not know }\end{array}$ \\
\hline
\end{tabular}

Table 3 The question groups of the interview concerning spirituality, the developed categories, and the main categories used for content analyses.

In our study. out of the total 242 PIL and PlaceIL answers, only 11 belonged to the Extrinsic subscale group and only 7 answers belonged to the independent Physical Health subscale. For this reason, we developed our MCs based only on the three Intrinsic subscales (Self-Acceptance, Affiliation, Community Feeling) of the Hungarian version of the Aspiration Index.

For the QG 'Purpose in life' we grouped our categories into the following MCs: 1.) personal improvement 2.) important social connections 3.) social 
commitment. MC 'Does not have a purpose in life' was not developed, since all participants mentioned at least one purpose in their lives.

For QG 'Place in life' the MCs are as follows: 1.) personal improvement 2.) important social connections 3.) social commitment 4.) did not find place.

The 6 categories of QG 'Faith' were also reduced to 3 MCs: 1.) has some kind of a belief-system 2.) has a belief system that helps her in her everyday life 3.) does not believe.

The 8 categories of QG 'Sharing with others' were reduced into 4 MCs: 1.) does not have 2.) has, a family member 3.) has, wider social structure 4.) not classifiable.

The 5 categories of QG 'Perceived control' were reduced to four MCs: 1.) perceives control 2.) does not perceive control 3.) partly perceives control, 50$50 \%$ 4.) not classifiable. Table 3 shows the MCs for each question group.

For further statistical analyses, MCs were used as analytic variables, while not classifiable answers were omitted.

It is to be noted that concerning one interview and QG codes belonging to certain MCs could be given by raters simultaneously or exclusively. In QGs 'Purpose in life', 'Place in life', and 'Sharing with others' codes belonging to more MCs could be given by raters simultaneously (e.g. 'Yes, with her goals coming true' and 'Yes, through helping others'), while in QGs 'Faith' and 'Perceived control' only one of the MC's codes (e.g. Does not believe in any belief system) could be used by raters.

\section{RESULTS}

\section{Inter-rater reliability}

As mentioned above, two raters classified the written texts of the interviews into 54 categories. As the data of the study is nominal and as the ratings have no natural ordering, Cohen's kappa was used in order to determine the degree of agreement between the two raters. Inter-rater agreement is considered to be almost perfect if the value of Cohen's kappa is between 0.81-1, and substantial, if the value is between 0.61-0.80.

Cohen's kappa was calculated for each question group of the interviews (Table 4).In all cases, the inter-rater agreements achieved at least the substantial level, and since Cohen's kappa is known to be a strict measure of interrater reliability, the agreement for all QGs was accepted. Almost perfect agreement was reached in the cases of the following question-groups: 'Purpose in life' ( $\kappa=0.98)$, 'Place in life' ( $\kappa=0.94)$, and 'Perceived control' $(\kappa=0.86)$. Substantial agreement was reached in the cases of the following question-groups: 'Faith' $(\kappa=0.76)$ and 'Sharing with others' $(\kappa=0.77)$. 
According to the usual path of qualitative content analysis, following the consensus of the two independent raters, one of the rater's data was used for developing the MCs, and for further statistical analysis.

\begin{tabular}{lccc}
$\begin{array}{l}\text { QUESTION } \\
\text { GROUPS }\end{array}$ & $\begin{array}{c}\text { NUMBER OF } \\
\text { ANSWERS }\end{array}$ & $\begin{array}{c}\text { NUMBER OF CATEGORIES } \\
\text { (CODES)/ NUMBER OF } \\
\text { MAIN CATEGORIES }\end{array}$ & COHEN'S KAPPA \\
\hline Faith & 59 & $6 / 3$ & $\mathrm{k}=0.76$ \\
\hline Purpose in life (PIL) & 153 & $20 / 3$ & $\mathrm{k}=0.98$ \\
\hline Place in life (PlacelL) & 89 & $15 / 4$ & $\mathrm{k}=0.94$ \\
\hline Sharing with others & 75 & $8 / 4$ & $\mathrm{k}=0.77$ \\
\hline Perceived control & 49 & $5 / 4$ & $\mathrm{k}=0.86$ \\
\hline
\end{tabular}

Table 4 The number of answers, categories, and main categories of the 5 question groups of the interviews regarding spirituality.

Altogether, 425 answers and 54 categories were identified, and 18 MCs were developed. Cohen's kappa shows the inter rater agreement in the classification of recognized answers into categories in each QG.

The comparison of the breast cancer patient and the control group

In order to define the differences between the groups $\mathrm{BC}$ and $\mathrm{HC}$, Chi-square test was performed on all MCs. There were no significant differences between the answers of the groups BC and the HC in the MCs of QGs 'Purpose in life', 'Place in life', 'Sharing with others', and 'Perceived control'.

However, a significant difference was found between the two groups in QG 'Faith' namely in MCs ('Has some kind of a belief-system' and 'Has a belief system and it helps her in her everyday life').

Both groups could be characterized as adhering to a certain faith... in the interviews, the codes belonging to the MCs 'Has some kind of a belief-system' and 'Has a belief system and it helps her in her everyday life' appeared more often (in $73 \%$ of BC patients' and $67 \%$ of the group $\mathrm{HC}$ interviews) than the codes belonging to MC 'Does not believe' (in 27\% of BC patients' and 33\% of group $\mathrm{HC}$ interviews).

The meaning of 'having a certain faith' was analyzed more thoroughly so that differences between groups BC and HC could be discovered. Members of group BC indicated it significantly more often that they not only have a general kind of a belief system (MC 'Has some kind of a belief system'), but that they have a belief system that is more specific, and it helps them to deal with their everyday lives MC 'Has a belief system that helps her in her everyday life', Chi-square=3.66, $d f=1, p=0.05$ ). On the contrary, the answers of group HC belonged to $\mathrm{MC}$ 'Has some kind of a belief-system' significantly more often than to MC 'Has a belief system that helps her in her everyday life' (chisquare $=4.722, \mathrm{df}=1, \mathrm{p}=0.03$ ). 


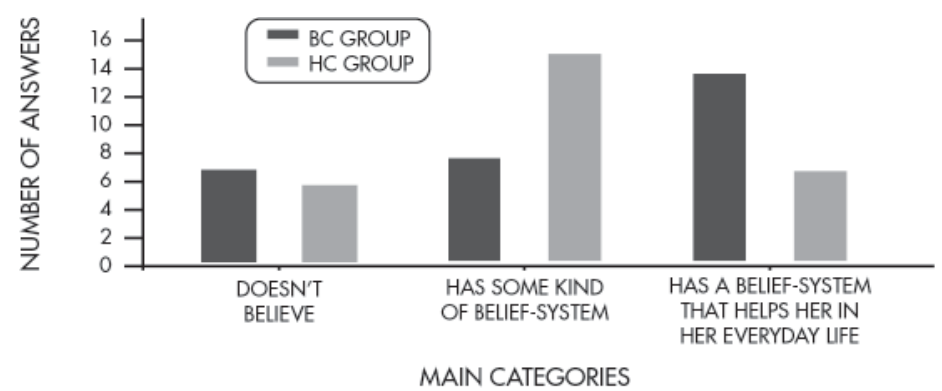

Figure 1 The frequencies of the given answers in each main category of question group 'Faith'.

Pattern exploring analysis

In order to further explore the possible differences between the BC patients and group $\mathrm{HC}$, the exploration of inside patterns within the sample groups was indispensable. The statistical analysis was done by Cochran's Q test which is the extension of the McNemar's test for related samples and binary $(0 ; 1)$ responses. It is a method for testing differences among three or more matched sets of frequencies or proportions. The test can tell whether the answers were evenly or differently distributed or not in groups $\mathrm{BC}$ or $\mathrm{HC}$ and within one question-group.

According to the frequencies, salient categories can be determined. Table 5 shows the number of answers by MCs and the significant Cochran's Q values for the significantly different proportion of these answers in both the $\mathrm{BC}$ and HC groups:

\section{Faith}

The Cochran's Q test did not show significant difference among the frequencies of answers of the 3 main categories in group BC. This means that although a growing tendency of proportion can be observed, there was no significant difference between the distribution of answers for the absence of faith (MC 'Does not believe'), for the MC 'Has some kind of a belief system', and for $\mathrm{MC}$ 'Has a belief system that helps her in her everyday life'. However, in the case of group HC, Cochran's Q test showed a tendency of difference in the pattern of the answers for the $3 \mathrm{MCs}$. According to the frequencies, out of the 3 types of answers, the MC of 'Has some kind of a belief system' emerged. Table 5 shows the frequencies of answers within the MCs of QG 'Place in life' for both sample groups. 


\begin{tabular}{|c|c|c|c|c|c|}
\hline \multirow[b]{2}{*}{$\begin{array}{l}\text { QUESTION } \\
\text { GROUPS }\end{array}$} & \multirow[b]{2}{*}{$\begin{array}{l}\text { MAIN } \\
\text { CATEGORIES }\end{array}$} & \multicolumn{2}{|c|}{ GROUP BC } & \multicolumn{2}{|c|}{ GROUP HC } \\
\hline & & ANSWERS & $\begin{array}{l}\text { SIG. } \\
\text { COCHRAN'S Qs }\end{array}$ & ANSWERS & $\begin{array}{c}\text { SIG. } \\
\text { COCHRAN'S Qs }\end{array}$ \\
\hline \multirow[t]{3}{*}{ Faith } & $\begin{array}{l}\text { 1. Has some kind of } \\
\text { a belief-system }\end{array}$ & 8 & & 15 & $\begin{array}{c}Q=5.214 \\
d f=2\end{array}$ \\
\hline & $\begin{array}{l}\text { 2. Has a belief system } \\
\text { that helps her in } \\
\text { her everyday life }\end{array}$ & 14 & & 7 & $\begin{array}{c}\mathrm{p}<0.074 \\
\text { (tendency only) }\end{array}$ \\
\hline & 3. Does not believe & 7 & & 6 & \\
\hline \multirow[t]{3}{*}{ Purpose in life } & 1. Personal improvement & 14 & $Q=6.091$ & 14 & \\
\hline & $\begin{array}{l}\text { 2. Important social } \\
\text { connections }\end{array}$ & 21 & $\begin{array}{c}d f=2 \\
p=0.048\end{array}$ & 16 & \\
\hline & 3. Social commitment & 12 & & 15 & \\
\hline \multirow[t]{4}{*}{ Place in life } & 1. Personal improvement & 12 & $Q=18.00$ & 18 & $Q=26.00$ \\
\hline & $\begin{array}{l}\text { 2. Important social } \\
\text { connections }\end{array}$ & 2 & $\begin{array}{c}d f=3 \\
p<0.000\end{array}$ & 5 & $\begin{array}{c}d f=3 \\
p<0.000\end{array}$ \\
\hline & 3. Social commitment & 2 & & 0 & \\
\hline & 4. Did not find place & 14 & & 12 & $Q=16.64$ \\
\hline Sharing & 1. Does not have & 6 & & 4 & $d f=2$ \\
\hline \multirow[t]{2}{*}{ with others } & 2. Has, a family member & 8 & & 8 & $p<0.000$ \\
\hline & 3. Has, wider social structur & ture 14 & & 20 & \\
\hline \multirow[t]{3}{*}{ Perceived control } & 1. Perceives control & 17 & $Q=14.84$ & 18 & $Q=22.52$ \\
\hline & 2. Does not perceive contr & trol 1 & $d f=2$ & 0 & $d f=2$ \\
\hline & $\begin{array}{l}\text { 3. Partly perceives } \\
\text { control } 50-50 \%\end{array}$ & 8 & $p=0.001$ & 5 & $\mathrm{p}<0.000$ \\
\hline
\end{tabular}

Table 5 The number of answers by question groups, main categories and the significant Cochran's $Q$ values for the significantly different distribution of answers.

Purpose in Life

The Cochran's $Q$ test showed significant differences in the frequencies of answers for the MCs of QG 'Purpose in life' in the case of BC patients. According to the distribution of answers, the MC of 'Important social connections' (family, children) emerged as goal and purpose in life emerged (Cochran's $Q=6.091$, $\mathrm{df}=2, \mathrm{p}=0.048$ ). In group HC Cochran's $\mathrm{Q}$ test did not show significant difference among the frequencies of answers in the 3 MCs. Group HC could be characterized as having found the purpose of their lives, evenly distributed in three groups, namely 'Personal Improvement', 'Important Social Connections', and 'Social Commitment'. Figure 2 shows the frequencies of answers in the MCs of QG 'Purpose in life' for both sample groups.

Place in Life

Both in groups BC and HC Cochran's Q test showed significant difference in the distribution of answers given for the $4 \mathrm{MCs}$ of QG 'Place in life'. 


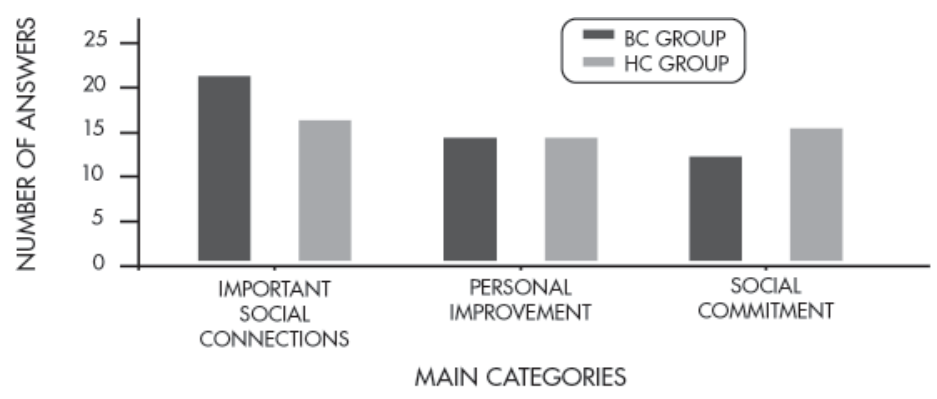

Figure 2 The distribution of answers in the 3 main categories of question group 'Purpose in life'.

While in group BC (Cochran's $Q=18.00 \mathrm{df}=3, \mathrm{p}=0.000)$, MCs 'Important social connections' and 'Social commitment' had low frequencies, in group HC (Cochran's $\mathrm{Q}=26.00 \mathrm{df}=3, \mathrm{p}<0.000$ ) the $\mathrm{MC}$ of 'Personal improvement' emerged. It is important to note that the occurrence rate of not finding one's place in a certain aspect of life was relatively high in both groups, almost half of each group mentioned that they did not find their place in life in one or more aspects, or in general. Table 5 shows the frequencies of answers within the MCs of QG 'Place in life' for both sample groups.

Sharing with others

In the case of group BC, Cochran's Q test did not show a difference in frequencies among the MCs. Although there was a growing tendency in the frequencies of answers, BC patients answered evenly distributedly the three possible answers: they did not have anybody to share these thought with, they share them with family members or they share them in a wider community (e.g.: friends or colleagues). In group HC Cochran's $Q$ test showed a significant difference in the patterns of answers (Cochran's $Q=16.64 \mathrm{df}=2, \mathrm{p}<0.000$ ). They wider community was mentioned more frequently as a forum of sharing. Table 5 shows the frequencies of answers within the MCs of QG 'Sharing with others' for both sample groups.

\section{Perceived control}

Both in groups BC and HC, the Cochran's Q test showed a significant difference in the frequencies of answers in the $3 \mathrm{MCs}$ of QG 'Perceived control' (BC group: Cochran's $Q=14.84$ df=2, $p=0.001, H C$ group: Cochran's $Q=22.52 \mathrm{df}=2, \mathrm{p}<0.000$ ). In both groups, women perceived control over constructs of believing, finding place and purpose in life. Table 5 shows the frequencies of answers in the MCs of QG 'Perceived control' for both groups. 


\section{DISCUSSION}

There are complex bio-psycho-social factors in the background of the incidence of breast cancer. Based on this premise, we developed the CCSI-BCP structured interview that was used for exploring attitudes and characteristics of people suffering from this malignant disease. As an important part of bio-psychosocial factors determining breast cancer, spirituality was thoroughly examined in our study. According to our results, a detailed picture was outlined about the compound attitudes of Hungarian women diagnosed with breast cancer towards the broadly interpreted topic of spirituality (faith, religiosity, purpose in life, place in life, sharing thoughts and perceived control concerning spirituality). Our study is mainly explorative and descriptive in nature, containing comparative elements that can give evidence based guidelines to develop clinical supportive therapies.

28 breast cancer patients and 28 healthy women were interviewed and compared in this study that focused on attitudes towards 5aspects of spirituality. Based on our results, no significant difference was found between breast cancer (BC) and healthy control (HC) groups in the dimensions (question groups of the interview) of 'Purpose in life', 'Place in life', 'Sharing with others', and 'Perceived control'. A significant difference was found, however, between the two groups in the dimension of faith. While both sample groups could be characterized as predominantly having a certain faith, it was noticed, that there is a difference in the intensity of spiritual belief between the groups $\mathrm{BC}$ and $\mathrm{HC}$.

Members of group BC indicated it significantly more often than members of group $\mathrm{HC}$ group that they not only have a general belief system that gives a framework of perception in general, but that they have a more specific belief system that helps them to deal with their everyday lives and that it is an active aid in coping with their illness.

The difference between the two groups can be explained by the psychological needs of patients facing a life threatening disease. Religious beliefs help to find order and framework of meaning to an otherwise chaotic and unpredictable world (Carone \& Barone, 2001), while uncontrollable events can be understood and interpreted by God-mediated control, that provides a sense of psychological control as well (Krause, 2005). According to Siegel, Anderman and Schrimshaw (2001), one function of religion is that it provides an interpretive framework or cognitive schema leading to better adjustment to health-related stressors. Religion, besides giving emotional and social support for breast cancer patients, also provides means for finding meaning in their everyday lives particularly during their cancer experiences (Feher \& Maly, 1999).

The greater importance of a belief system that affects and helps everyday life, and the importance of family for women in the breast cancer group of this 
study, might be explained by the 'Psychological object relations' theory. This theory posits that humans construct and relate to internal representations of themselves, of other people, and entities such as God. In this sense, God representations may function psychologically like social relationships for comfort and anxiety management (Winnicott, 1953, 1966, 1971 cited by Bowman, Beitman, Palesh, Pérez \& Koopman, 2009).

Our further findings describe the similarities and differences of the patterns of answers within groups BC and HC for the question groups 'Faith', 'Purpose in life', 'Place in life', 'Sharing with others', and 'Perceived control', but the results should be treated with caution as even significant results show only relative frequencies within one group.

While in group HC, answers for the question group 'Purpose in life' was evenly distributed, the breast cancer sample group indicated meaningful social relationships (children and family) as important purposes in life. Similar results are presented by O'Connor, Wicker, and Gemino (1990) who examined the meaning-making process of recently diagnosed cancer patients and found faith and social support as two important factors of finding meaning in the face of an uncontrollable situation. Bauer \& Farran (2005) also found in a comparative study of breast cancer survivors and healthy women that breast cancer survivors without children had less meaningful lives, greater stress and distress than breast cancer survivors with children and healthy women without cancer.

This finding goes together with our results that meaningful social relationships are important purposes in life for women dealing with this illness. However it is thought-provoking why cancer patients rarely mention social relationships as forums where they have found their place in life. It would be interesting to further investigate the reason behind this phenomenon.

For QG 'Place in life', group HC mainly answered with MC 'Personal improvement'. In both sample groups, the proportion of answers for $\mathrm{MC}$ 'Did not find place' (that means not finding place in one or more areas of life) was relatively high, almost half of both samples gave this answer in this $\mathrm{MC}$.

Within the responses to the question 'Do you have somebody to share your thoughts with about the above topics, or are you, for example, a member of a congregation' (QG Sharing with others) the proportion of answers were not significantly differentiated in the BC group, while in group $\mathrm{HC}$, there was a significant difference in the distribution of answers, and the $\mathrm{MC}^{\prime}$ Wider social circle' (friends and colleagues) emerged.

Again, these findings can be contrasted in the case of group $\mathrm{BC}$ with the answers for QG 'Purpose in life'. Although BC patients seem to find family as an important purpose in life, the sharing of important topics such as spirituality is lacking.

Overall, BC patients tended to find meaningful social relationships (family, children) as important purposes in life; however, neither do they find their 
places in important social relationships, nor do they share thoughts about spirituality with their family members.

Both groups experienced a perceived control over finding meaning and place in life and finding faith.

According to these findings, it would be important for the clinical practice to take into consideration the belief system and the spiritual cognitive schema of patients, and to design their treatments in accordance with and based on them, since they provide resources for coping with illness, and for psychological well-being and adjustment.

To further explore the role of the family and important social connections for breast cancer patients facing life threatening illness, those parts of the interview that focus especially on social structure and important relationships of $\mathrm{BC}$ patients and healthy women will be analyzed and compared with the present findings.

Although our study explores important patterns and connections, there are some limitations to be aware of. The sample size of the study was relatively high compared to a qualitative study, but a greater sample size would be more effective for statistical analyses. The face-to-face interviews allowed us to gather more detailed information from the participants, but the complexity of qualitative analyses was unavoidably less objective than a standardized self-reporting questionnaire.

\section{CONCLUSIONS}

According to our findings, in this sample group, breast cancer patients and healthy women seem to be more similar than different in the questions of broadly interpreted spirituality (e.g.: belief systems, purpose in life, place in life). Some slight differences were shown in our results, indicating that while healthy women have a general framework of belief, breast cancer patients perceive religion as an active aid affecting everyday life. 


\section{REFERENCES}

Bauer-Wu, S., \& Farran, C. J. (2005). Meaning in Life and Psycho-Spiritual Functioning. A Comparison of Breast Cancer Survivors and Healthy Women. Journal of Holistic Nursing, 23(2), 172-190.

Baumeister, R. F. (1991). Meanings of life. New York: Guilford Press.

Bergin, A. E. (1983). Religiosity and mental health: A critical reevaluation and meta-analysis. Professional psychology: Research and practice, 14(2), 170-184.

Bowman, E. S., Beitman, J. A., Palesh, O., Pérez, J. E., \& Koopman, C. (2009). The Cancer and Deity Questionnaire: A New Religion and Cancer Measure. Journal of Psychosocial Oncology, 27(4), $435-453$.

Carone, D., \& Barone, D. (2001). A social cognitive perspective on religious beliefs: their functions and impacts on coping and psychotherapy. Clinical Psychology Review, 21(7), 989-1003.

Charmaz, K. (2000). Grounded theory. Objectivist and constructivist methods. In Denzin, N. K. \& Lincoln, Y. S. (Eds.), Handbook of qualitative research (509-535). Thousand Oaks: Sage Publications, Inc.

Charmaz K., \& Henwood, K. (2008). Grounded theory. In Willig, C. \& Stainton-Rogers, W. (Eds.), The Sage handbook of qualitative research in psychology (240-260). London: Sage Publishers Ltd.

Coward, D. D. (2003). Self-Transcendence in a Breast Cancer Support Group: II, Oncology Nursing Forum, 30(2), 291-300.

Crumbaugh, J. \& Maholick, L. T. (1964). An experimental study in existentialism: The psychometric approach to Frankl's concept of noogenic neurosis. Journal of Clinical Psychology, 20(2), 200-207.

Crumbaugh, J. (1968). Cross-validation of purpose in life test based on Frankl's concepts. Journal of Individual Psychology, 24, 74-81.

Deci, E. L., \& Ryan, R. M. (1987). The support of Autonomy and the Control of Behavior. Journal of Personality and Social Psychology, 53(6), 1024-1037.

Deci, E. L., \& Ryan, R. M. (2002). Handbook of self-determination research. NewYork: Universty of Rochester Press.

Dormán, J., Martos, T., \& Urbán, Sz. (2012). Vallásosság és poszttraumás növekedés: egy többdimenziós megközelítés [Religiosity and posttraumatic growth: A multidimensional approach]. Mentálhigiéné és Pszichoszomatika, 13(1), 21-35.

Emblem, J. D. (1992). Religion and spirituality defined according to current use in nursing literature. Journal of Professional Nursing, 8(1), 41- 47.

Farkas, L., \& Gerevich, J. (2005). Vallásosság és egészség kapcsolatának kutatása: elméleti kontextus [The research of the connection between religiosity and health: theoretical context]. Egészségfejlesztés, 46(3): 23-27.

Feher, S., \& Maly, R. C. (1999). Coping with breast cancer in later life: The role of religious faith. Psycho-Oncology, 8, 408-416.

Fehring, R.J., Miller, J. F., \& Shaw, C. (1997). Spiritual well-being, religiosity, hope, depression, and other mood states in elderly people coping with cancer. OncologicalNursing Forum, 24(4),663671.

Ferlay, J., Steliarova-Foucher, E., Lortet-Tieulent, J., Rosso, S., Coebergh, J. W., Comber, H., Forman, 
D., \& Bray, F. (2013). Cancer incidence and mortality patterns in Europe: estimates for 40 countries in 2012. European Journal of Cancer. 49(6), 1374-403.

Fiala, W. E., Bjorck, J. P., \& Gorsuch, R. (2002). The religious support scale: Construction, validation, and cross-validation. American Journal of Community Psychology, 30(6), 761-786.

Frankl, V. E. (1959). Grundgrib der Existenzanalyse und Logotherapie / Az egzisztenciaanalízis és logoterápia alapjai. In Sárkány \& P., Zsók, O. (Eds.) (2010). Die Grundlagen der Logotherapie Eine zweisprachige Textsammlung. / A logoterápia alapjai - Kétnyelvú szöveggyüjtemény. Budapest: Jel Kiadó.

Frankl, V. E. (2006). Értelem és egzisztencia: előadások és tanulmányok [Sense and existence: lectures and studies]. In Batthyány, A. \& Sárkány, P. (Eds.) Értelem és egzisztencia: előadások és tanulmányok. Budapest: Jel Kiadó.

George, L. K., Larson, D. B., Koenig, H. G., \& McCullough, M. E. (2000). Spirituality and health: What we know, what we need to know. Journal of social and clinical psychology, 19(1), 102116.

Glaser, B. G., \& Strauss, A. L. (1967). The Discovery of Grounded theory: Strategies for Qualitative Research. Chicago: Aldine.

Hammer Zs. (1995). Tüdốrákos betegek megküzdési stratégiái [Coping strategies of patients with lung cancer]. Theses (MA). Budapest: ELTE.

Herek, G. M. (1987). Religious Orientation and Prejudice: A Comparison of Racial and Sexual Attitudes. Personality and Social Psychology Bulletin, 13(1),34-44.

Hill, P. C., \& Pargament, K. I. (2008). Advances in the conceptualization and measurement of religion and spirituality: Implications for physical and mental health research. American Psychologist, 58(1), 64-74.

Holland, J. C., Passik, S., Kash, K. M., Russak, S. M., Gronert, M. K., Sison, A., Lederberg M., Fox, B., \& Baider, L. (1999). The role of religious and spiritual beliefs in coping with malignant melanoma. Psycho-Oncology, 8(1), 14-26.

Horváth-Szabó, K., Harmatta, J., \& Tomcsányi, T. (2009). Teisztikus és humanisztikus spiritualitás (Theistic and humanistic spirituality), Pszichoterápia, 18(3), 173-179.

Hungarian Central Statistical Office (2013) http://statinfo.ksh.hu/Statinfo/themeSelector. jsp?\&lang=en, download: 06.06.2013.

Jenkins, R. A., \& Pargament, K. I. (1995). Religion and spirituality as resources for coping with cancer. Journal of Psychosocial Oncology, 13, 51-74.

Johnson, S. C., \& Spilka, B. (1991). Coping with breast cancer: The roles of clergy and faith. Journal of Religion and Health, 30(1), 21-33.

Jonsén, E., Lundman, B., Nygren, B., Vähäkangas, M., \&Strandberg, G. (2010). Psychometric properties of the Swedish version of the Purpose in Life scale. Scandinavian Journal of Caring Sciences, 24(1), 41-48.

Kaczorowski, J. M. (1990). Spiritual Well-Being and Anxiety in Adults Diagnosed with Cancer. The Hospice Journal, 5(3-4), 105-116.

Kasser, T., \& Ryan, R. M. (1996). Further examining the American Dream: Differential Correlates of Intrinsic and Extrinsic Goals. Personality andSocial Psychology Bulletin 22, 281-288.

Kézdy, A., \&Martos T. (2007). A vallásosság szerepe a személyes célok rendszerében. [The role of 
religiosity in the personal set of beliefs.] In Horváth-Szabó, K. (Eds.),Vallásosság és személyiség, Budapest: PPKE BTK.

Kézdy, A. (2010). Fejlődési krizisek késő serdüló- és fiatal felnóttkorban. A vallásosság jellegzetességei és összefüggései a lelki egészséggel középiskolás és egyetemista mintában [Characteristics of religiosity and its associations with mental health in a high school and university student sample]. PhD Theses. School of PhD Studies, School of Mental Health Sciences, Budapest: Semmelweis University.

Kézdy, A., Martos, T., Urbán, Sz., \& Horváth-Szabó, K. (2010) A vallásos attitûd, a megküzdés és a lelki egészség összefüggései: azonosságok és különbségek serdülő- és fiatal felnőttkorban [The relationship between religious attitudes, coping strategies, and mental health in adolescence and young adulthood]. Mentálhigiéné és Pszichoszomatika, 11(1), 1-16.

Konkoly Thege, B., \& Martos, T. (2006). Az életcél kérdőív magyar változatának jellemzői [Purpose in Life Test - Characteristics of the Hungarian Adaptation]. Mentálhigiéné és Pszichoszomatika, 7(3), 153-169.

Konkoly Thege, B., Martos, T., Skrabski, Á., \& Kopp, M. (2008). A Rövidített Stressz és Megküzdés Kérdőív élet értelmességét mérő alskálájának (BSCI-LM) pszichometriai jellemzői [Psychometric properties of the life meaning subscale from the Brief Stress and Coping Inventory (BSCI-LM)]. Mentálhigiéné és Pszichoszomatika, 9(3), 243-261.

Kopp, M., Székely, A., \& Skrabski, Á. (2006). A vallásosság és életminőség az átalakuló társadalomban [Religiosity and Quality of Life in an altering society]. In Kopp M., Kovács M. E. (Eds.) A magyar népesség életminősége az ezredfordulón [The Quality of Life of the Hungarian population on the millenary], Budapest: Semmelweis Kiadó.

Krause, N. (2005). God-mediated control and psychological well-being in late life. Research on Aging, 27(2), 136-164.

Lee, V., Cohen S. R., Edgar L., Laizner A. M., \& Gagnon A. J., (2006). Meaning-Making and Psychological Adjustment to Cancer: Development of an Intervention and Pilot Results. Oncology Nursing Forum, 33(2), 291-302.

Malvezzi, M., Bertuccio, P.,Levi, F.,La Vecchia, C., \& Negri, E. (2013). European cancer mortality predictions for the year 2013. Annals of Oncology, 24, 792-800.

Martos, T., Szabó, G., \& Rózsa. S. (2006). Az aspirációs index rövidített változatának pszichometriai jellemzői hazai mintán. [Psychometric Characteristics of the Shortened Aspiration Index in Hungarian Sample.] Mentálhigiéné és Pszichoszomatika, 7(3), 171-191.

Martos, T. (2007). Vallásosság és az értelmes élet pszichológiája [Religiosity and the psychology of meaningful life]. In Horváth-Szabó K. (Eds.) Vallásosság és személyiség. Budapest: PPKE.

Martos, T., \&Kézdy, A. (2007). Vallásosság, lelki egészség, boldogság [Religiosity, mental health and happiness], In Horváth-Szabó, K. (Eds.) Vallásosság és személyiség, Budapest: PPKE.

Martos, T., Kézdy, A., Robu, M., Urbán, Sz., \& Horváth-Szabó, K. (2009). Újabb adatok a Kritika Utáni Vallásosság Skála alkalmazásához - elmélet és módszertan [New data for the application of the Post Critical Belief Scale - Theory and methodology]. Magyar Pszichológiai Szemle, 64(4), 643-669.

Martos, T., Kézdy, A., \&Horváth-Szabó, K. (2011). Religious motivations for everyday goals: their religious context and potential consequences, Motivation and emotion, 35(1), 75-88.

Masters, K. S., Hill, R. D., Kircher, J. C., Benson, T. L. L., \& Fallon, J. A. (2004). Religious orientation, 
aging, and blood pressure reactivity to interpersonal and cognitive stressors. Annals of Behavioral Medicine, 28(3), 171-178.

McClain-Jacobson, C., Rosenfeld, B., Kosinski, A., Pessin, H., Cimino, J.E., \& Breitbart, W. (2004). Belief in an afterlife, spiritual well-being and end-of-life despair in patients with advanced cancer. General Hospital Psychiatry, 26, 484- 486.

McCullough, M. E., \& Larson, D. B. (1999). Religion and depression: A review of the literature. Twin Research, 2, 126-136.

Mersdorf A., Vargay A., Horváth Zs. \& Bányai É. (2013) „Mit gondol, van-e az életének célja és értelme? Ha igen, mi?" Emlődaganatos betegek és egészséges kontrollszemélyek interjúkérdésekre adott válaszainak összehasonlítása. ['Do you think your life has a purpose and a meaning? In case yes, what's that?' Comparing the answers of breast cancer patients and healthy women given during a structured interview.] Mentálhigiéné és Pszichoszomatika, 14(4), 345-380.

Miller, W. R., \& Thoresen, C. E. (2003). Spirituality, religion, and health: An emerging research field. American psychologist, 58(1), 24-35.

Muldoon, M., \& King, N. (1995). Spirituality, health care, and bioethics. Journal of Religion and Health, 34, 329-49.

Muhr, T. (1997). Atlas/ti - Visual qualitative data analysis. Management - Model building -Release 4.1 User's Manual. Berlin: Scientific Software Development.

O'Connor, A. P., Wicker, C. A., \& Germino, B. B. (1990). Understanding the cancer patient's search for meaning. Cancer Nursing, 13(3), 167-175.

Pargament, K. I. (2001). The psychology of religion and coping: Theory, research, practice. New York: Guilford Press.

Payne, I. R., Bergin, A. E., Bielema, K. A., \& Jenkins, P. H. (1991). Review of religion and mental health: Prevention and the enhancement of psychosocial functioning. Prevention in Human Services, 9(2), 11-40.

Pinquart, M., Silbereisen, R. K., \& Fröhlich C. (2009). Life goals and purpose in life in cancer patients. Supportive Care in Cancer, 17(3), 253-259.

Powell, H. L., Shahabi, L., \& Thoresen C. E. (2003). Religion and Spirituality: Linkages to Physical Health. American Psychologist, 58(1), 36-52.

Sarvimaki, A., \& Stenbock-Hult, B. (2000). Quality of life in old age described as a sense of wellbeing, meaning and value. Journal of Advanced Nursing, 32, 1025-33.

Siegel, K., Anderman, S. J., \& Schrimshaw, E.W. (2001). Religion and coping with health-related stress. Psychology \& Health, 16(6), 631-653.

Strauss A. L. (1987). Qualitative analysis for social scientists. Cambridge: Cambridge University Press. Susánszky, É., \& Riskó, Á. (2006). „Élet a betegség után.” Sikeresen kezelt rosszindulatú daganatos betegek életminőségének vizsgálatat ['Life after illness'. The Quality of Life of succesfully treated oncological patients]. In Kopp M., Kovács M. E. (Eds.) A magyar népesség életminősége az ezredfordulón [The Quality of Life of the Hungarian population on the millenary]. Budapest: Semmelweis Kiadó.

Tomcsányi, T., Martos, T., Ittzés, A., Horváth-Szabó, K., Szabó, T., \& Nagy, J. (2011). A Spirituális Transzcendencia Skála hazai alkalmazása: elmélet, pszichometriai jellemzők, kutatási 
eredmények és rövidített változat [Application of the Spiritual Transcendence Scale in Hungary: Theory, psychometric properties, empirical findings and shortened version]. Pszichológia, 31(2), 165-192.

Turner, R. J., \& Marino, F. (1994). Social Support and Social Structure: A Descriptive Epidemiology. Journal of Health and Social Behaviour. 35, 193-212.

V. Komlósi, A., Rózsa, S., \& Móricz, É. (2006). Az Aspirációs index hazai alkalmazásával szerzett tapasztalatok [Results of the Hungarian application of the Aspiration Index]. Magyar Pszichológiai Szemle, 61(2), 237-250.

Komlósi, J. E., \& Gandek, B., The IQOLA Project Group. (1994). The SF-36® Health Survey: development and use in mental health research and the IQOLA Project. International Journal of Mental Health, 23(2), 49-73.

Ware, J. E. (2002). SF-36® Health Survey Update 2002 www.sf-36.org/tools/SF36.shtml

Yates, J. W., Chalmer, B. J., St. James, P., Follansbee, M., \& McKegney, F. P. (1981). Religion in patients with advanced cancer. Medical and Pediatric Oncology, 9,121-128. 